\title{
Status of vitamins $E$ and $A$ and $\beta$-carotene and health in organic dairy cows fed a diet without synthetic vitamins
}

\author{
B. Johansson, ${ }^{\star 1}$ K. Persson Waller,†‡ S. K. Jensen,§ H. Lindqvist, ${ }^{\star}$ and E. Nadeau* \\ *Department of Animal Environment and Health, Swedish University of Agricultural Sciences, 53223 Skara, Sweden \\ †Department of Animal Health and Antimicrobial Strategies, National Veterinary Institute (SVA), 75189 Uppsala, Sweden \\ ‡Department of Clinical Sciences, Swedish University of Agricultural Sciences, 75007 Uppsala, Sweden \\ §Department of Animal Sciences, Aarhus University, 8830 Tjele, Denmark
}

\begin{abstract}
Synthetic vitamin supplementation is not consistent with organic production, so it is important to investigate whether dairy cows can maintain their health and production without synthetic vitamins being added to their diet. In basic dairy cow diets, provitamin A $(\beta$-carotene) and vitamin $\mathrm{E}$ are mainly found in pasture and in grass and legume silages, but the concentrations are highly variable. This study compared the vitamin status and health of cows without synthetic vitamin supplementation (NSV group) with control cows (CON group) fed synthetic vitamins according to Swedish recommendations (600 IU of vitamin $\mathrm{E}$ and 80,000 IU of vitamin A per cow per day) to investigate whether dairy cows can fulfill their requirements of vitamins $\mathrm{A}$ and $\mathrm{E}$ without supplementation with synthetic vitamins. Vitamin concentrations in blood plasma and milk, health, fertility, milk yield, and milk composition were measured in Swedish Holstein cows $(\mathrm{n}=28)$ during 2 complete lactations. All cows were fed a $100 \%$ organic diet containing grass-legume silage, cold-pressed rapeseed cake, peas, cereal grains, and minerals. Blood samples were collected from each cow 3 wk before expected calving, at calving, and $3 \mathrm{wk}, 3$ to $5 \mathrm{mo}$, and 7 to 9 mo after calving. Samples of colostrum were taken and milk samples were collected $4 \mathrm{~d}$ after calving and at the same time as the 3 blood samplings after calving. The only difference in vitamin status between groups was found in colostrum in yr 1 , when CON cows tended to have a higher concentration of $\alpha$-tocopherol, and their $\beta$-carotene concentration was higher compared with NSV cows. The NSV cows tended to have more cases of mastitis than CON cows in yr 2. Within the NSV group, fewer cows were healthy and more cases of mastitis were observed in yr 2 than in yr 1. The groups did not differ in production parameters. In conclusion, the vitamin status in blood and milk of the studied
\end{abstract}

Received August 19, 2013.

Accepted November 10, 2013.

${ }^{1}$ Corresponding author: Birgitta.Johansson@slu.se cows indicated that cows in organic dairy production can fulfill their requirements of vitamins $\mathrm{A}$ and $\mathrm{E}$ without any supplementation of synthetic vitamins, except at the time around calving, when the requirements are high. However, the impaired health of NSV cows in yr 2 may indicate a long-term negative health effect in cows fed no synthetic vitamins.

Key words: $\alpha$-tocopherol, $\beta$-carotene, retinol, organic milk production

\section{INTRODUCTION}

The international principles for organic farming do not approve the use of synthetic vitamins. Thus, diets for dairy cows in organic production must be based on naturally derived feeds (EC, 1999), and synthetic vitamins may only be used if required to fulfill the vitamin needs of the animals (EC, 2005). Consequently, it is important to investigate whether dairy cows can maintain their production and health throughout lactation without supplementation with synthetic vitamin $\mathrm{A}$ and $\mathrm{E}$.

In basic dairy cow diets, vitamin $\mathrm{E}$ is mainly found in grass and forage legumes but also in unprocessed oilseeds (NRC, 2001). The most important function of vitamin $\mathrm{E}$ is its antioxidant effect and thereby its positive effects on the immune system (e.g., mammary gland health; Politis et al., 1996; Weiss et al., 1997). Moreover, vitamin $\mathrm{E}$ is involved in maintaining the oxidative stability and flavor of milk (Vagni et al., 2011). Natural vitamin $\mathrm{E}(R R R$ - $\alpha$-tocopherol) found in feeds is not identical to synthetic vitamin $\mathrm{E}$ (all-rac- $\alpha$ tocopheryl acetate), and has higher biological activity than synthetic vitamin E (Meglia et al., 2006; DersjantLi and Peisker, 2010; Vagni et al., 2011).

Vitamin A activity is defined in retinol equivalents. Retinol is not found in plants, but many feeds contain $\beta$-carotene (provitamin A) and most $\beta$-carotene is found in vegetative material (NRC, 2001). Carotenes are converted to retinol by enzymes in the cow intestinal mucosa, but large amounts of $\beta$-carotene are also absorbed without modification (Chew, 1987). 
Vitamin A and $\beta$-carotene have many diverse functions such as in reproduction, immune functions, and health (Chew, 1993; Kume and Toharmat, 2001). Similar to vitamin E, $\beta$-carotene is an antioxidant (Chew, 1987, 1993).

Grass and legume silages have higher contents of vitamin $\mathrm{E}$ and $\beta$-carotene than hay, whole-crop small grain silage, or corn silage, as reflected in the concentrations of vitamin $E$ and $\beta$-carotene in milk from cows fed these different roughages (Agabriel et al., 2007; Mogensen et al., 2012). It has also been suggested that ruminal destruction of vitamin A decreases as the proportion of forage in the diet increases (Weiss et al., 1995). However, the concentrations of the natural forms of vitamin $\mathrm{E}(R R R$ - $\alpha$-tocopherol) and $\beta$-carotene in silages are highly variable and relatively unstable (Calderón et al., 2007; Lindqvist et al., 2011; Lindqvist et al., 2012). In contrast, the synthetic forms of vitamin A (e.g., all-trans retinyl acetate) and $\mathrm{E}$ (all-rac- $\alpha$-tocopheryl acetate) present in supplements are relatively stable throughout processing and storage (Coelho, 1991). Therefore, the amounts of vitamins fed to the cow are known more exactly when synthetic supplements are fed and, thus, the NRC recommends that the total vitamin $\mathrm{A}, \mathrm{D}$, and E requirements be met via dietary supplements (NRC, 2001).

In dairy cows, the highest need for vitamins occurs around calving, when the cows are exposed to physiological stress. Decreased DMI relative to milk production and vitamin losses with colostrum are not sufficient to explain the decrease, but vitamin partitioning may also be impaired (Drackley, 1999; Baldi, 2005).

The hypothesis in the present study was that organic feed rations based on high proportions of grass-legume silage of good nutritive value provide a substantial contribution of vitamins and thereby supply dairy cows with adequate amounts of $\alpha$-tocopherol and $\beta$-carotene, except during the transition period around calving, when the requirements are high. Therefore, experiments were conducted to investigate whether high-producing dairy cows in organic production can fulfill their requirements of vitamins $\mathrm{A}$ and $\mathrm{E}$ without any supplementation of synthetic vitamins when fed a diet based on organic feeds chosen for high vitamin contents. To evaluate this, 2 groups of dairy cows were monitored during 2 lactations.

\section{MATERIALS AND METHODS}

\section{Animals and Experimental Design}

The experiment was approved by the Research Animal Ethics Committee (Swedish Board of Agriculture, Jönköping, Sweden) and conducted during 2 complete lactation periods in 2 consecutive years at Tingvall Organic Dairy Research Farm in southwest Sweden, which was owned by the Swedish Rural Economy and Agricultural Societies (Uddevalla, Sweden). The herd consisted of Swedish Holstein dairy cows with a rolling herd average annual milk yield of 9,873 and $10,383 \mathrm{~kg}$ of ECM per cow during yr 1 and 2, respectively, with $3.7 \%$ fat and $3.3 \%$ protein in the milk in both years. The cows were milked twice per day at 0530 and 1530 h. From early May until mid October, the cows were kept out on pasture, except for about $3 \mathrm{~h}$ around each milking. During the indoor period, they were kept in a loose-housing system. The 2 experimental groups, each of which comprised 14 cows, were housed in separate pens.

Cows were paired according to their expected calving date, lactation number, and previous 305-d milk yield (or breeding index for heifers), and then randomly allocated to 1 of 2 treatments: a 100\% organic diet containing mineral feed without vitamins [no synthetic vitamins (NSV)] and a 100\% organic diet containing the same mineral feed but including the synthetic vitamins $\mathrm{A}, \mathrm{D}_{3}$, and $\mathrm{E}$ [control $(\mathbf{C O N})$ with synthetic vitamins]. Vitamin supplementation started during the dry period, at least 1 mo before expected calving, and continued during lactation. All cows calved between November and February in yr 1 and between August and March in yr 2.

\section{Diets}

During the housed period, the cows were fed a partially mixed ration of grass-clover silage and rolled barley (also triticale in yr 2) ad libitum, supplemented with a barley/pea mixture, cold-pressed rapeseed cake, and mineral feed, in transponder-controlled automatic feeders. Cows were fed a minimum of $50 \%$ silage (calculated on a DM basis) in the first 3 mo after calving and thereafter a minimum of $60 \%$ silage, according to the standards for organic feeds (EC, 1999).

The mineral feed included $146 \mathrm{~g}$ of Ca, $65 \mathrm{~g}$ of P, $92 \mathrm{~g}$ of $\mathrm{Mg}$, and $40 \mathrm{mg}$ of Se per kilogram of DM. For CON cows, it also included 3,000 IU of vitamin E, 100,000 IU of vitamin D, and 400,000 IU of vitamin A per kilogram of DM. Minerals and vitamins were fed according to Swedish recommendations, which are based on NRC (2001) guidelines. Dry cows in the CON group were supplemented with $450 \mathrm{IU}$ of vitamin $\mathrm{E}$ and $60,000 \mathrm{IU}$ of vitamin A per day in the diet from the start of the experiment until calving. The calculated daily amounts offered by the basal diet (based on $9 \mathrm{~kg}$ of silage DM) of the dry cow were approximately 173 IU of vitamin $\mathrm{E}$ and 9,420 IU of vitamin A. The vitamin contents in the diet of lactating cows are shown in Table 1. 
Table 1. Supplementation (suppl.) and calculated approximate total intake (suppl. plus vitamins in basal feeds) of vitamins E and A (IU per day) during the first $3 \mathrm{mo}$ of lactation when dairy cows were fed a diet containing a minimum of $50 \%$ forage, and in later lactation ( $>3$ mo) when the cows were fed a minimum of $60 \%$ forage, during yr 1 and $2^{1}$

\begin{tabular}{|c|c|c|c|c|c|c|c|c|}
\hline Vitamin $^{2}$ & \multicolumn{4}{|c|}{ 1-3 mo of lactation } & \multicolumn{4}{|c|}{$>3$ mo of lactation } \\
\hline Vitamin E, total ${ }^{4}$ & 1,531 & 2,131 & 1,421 & 2,021 & 1,392 & 1,992 & 1,298 & 1,898 \\
\hline Vitamin E, suppl. & - & 600 & - & 600 & - & 600 & - & 600 \\
\hline Vitamin , total ${ }^{5}$ & 278,981 & 358,981 & 239,858 & 319,858 & 278,700 & 358,700 & 239,472 & 319,472 \\
\hline
\end{tabular}

${ }^{1}$ Cows were not fed [no synthetic vitamins (NSV); $\left.\mathrm{n}=14\right]$ or fed [control $\left.(\mathrm{CON}) ; \mathrm{n}=14\right]$ synthetic vitamins.

${ }^{2}$ Synthetic vitamin E was provided as all-rac- $\alpha$-tocopheryl acetate. Synthetic vitamin A was provided as retinyl acetate.

${ }^{3}$ Vitamin $\mathrm{D}_{3}(20,000 \mathrm{IU} / \mathrm{d})$ was also supplemented in the mineral feed in the CON diet.

${ }^{4}$ Amount (IU) of basal vitamin $\mathrm{E}$ was calculated as $1.49 \times$ milligrams of $\alpha$-tocopherol from basal feeds.

${ }^{5}$ Amount (IU) of basal vitamin A was calculated as $400 \times$ milligrams of $\beta$-carotene from basal feeds.

During the grazing period, the majority of the silage was replaced by pasture and lactating cows were fed the 2 mineral feeds (with or without vitamins), concentrates, and some silage when indoors at milking. None of the dry cows was supplemented with vitamins during the grazing period, only minerals.

\section{Feed Sampling and Analyses}

Sampling. Grass-clover forage was ensiled in bunker silos and was stored for at least $60 \mathrm{~d}$ without using additives. Silage samples were taken daily and pooled to 1 composite sample per week for analysis of DM, 1 sample per month for analysis of vitamin content (Figure 1 and Table 2), and 1 sample per silo for analysis of other chemicals on a DM basis (Table 2). Sugar and fermentation characteristics were also determined on the silages (pH 4.1, $14 \mathrm{~g}$ of sugar, $104 \mathrm{~g}$ of lactic acid, $27 \mathrm{~g}$ of acetic acid, $<1.8 \mathrm{~g}$ of propionic acid, and $<0.1 \mathrm{~g}$ of butyric acid per kilogram of DM, averaged over indoor periods in yr 1 and 2). Concentrates were sampled once per week and pooled to 1 composite sample per batch for vitamin content and other chemical analyses (Table 2). Samples of baled silage for dry cows were analyzed for vitamin content and other chemical analyses (Table 2). Pasture samples were taken every month during the pasture period, analyzed for vitamin content, and pooled to 1 composite sample per period for analysis of other chemicals (Table 2).

Analyses. All vitamin analyses were performed at the Department of Animal Sciences, Research Centre Foulum, Aarhus University (Tjele, Denmark). Both silages and fresh herbages were freeze-dried before vitamin analysis, whereas concentrates were milled directly. The $\alpha$-tocopherol and $\beta$-carotene concentrations were determined by normal-phase HPLC after saponification and extraction into heptane according to Jensen and Nielsen (1996).

The DM concentration of silage was determined after drying at $60^{\circ} \mathrm{C}$ for $24 \mathrm{~h}$, whereas the DM concentration of concentrates was determined after drying at $103^{\circ} \mathrm{C}$ for $24 \mathrm{~h}$. Crude protein and NDF in forages and concentrates, crude fat in concentrates, and fermentation characteristics of the silages were analyzed at Eurofins Laboratories Inc. (Lidköping, Sweden), as described by Johansson and Nadeau (2006). Metabolizable energy concentration of silage was calculated from in vitro rumen OM digestibility. Metabolizable protein content, expressed as amino acids absorbed in the small intestine, and protein balance in the rumen were calculated from standards described by Madsen et al. (1995).

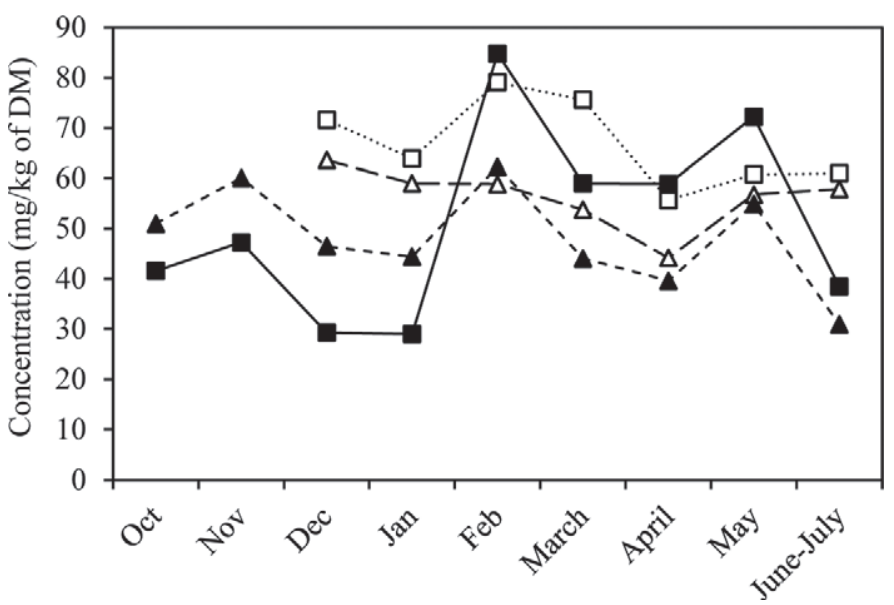

Figure 1. $\alpha$-Tocopherol concentrations in pooled monthly silage samples during yr $1(-\square-)$ and $2(-\mathbf{\square})$ and $\beta$-carotene concentrations in the same silage samples during yr $1(---\Delta---)$ and $2\left(---\mathbf{\Delta - - -}_{-}\right)$. 


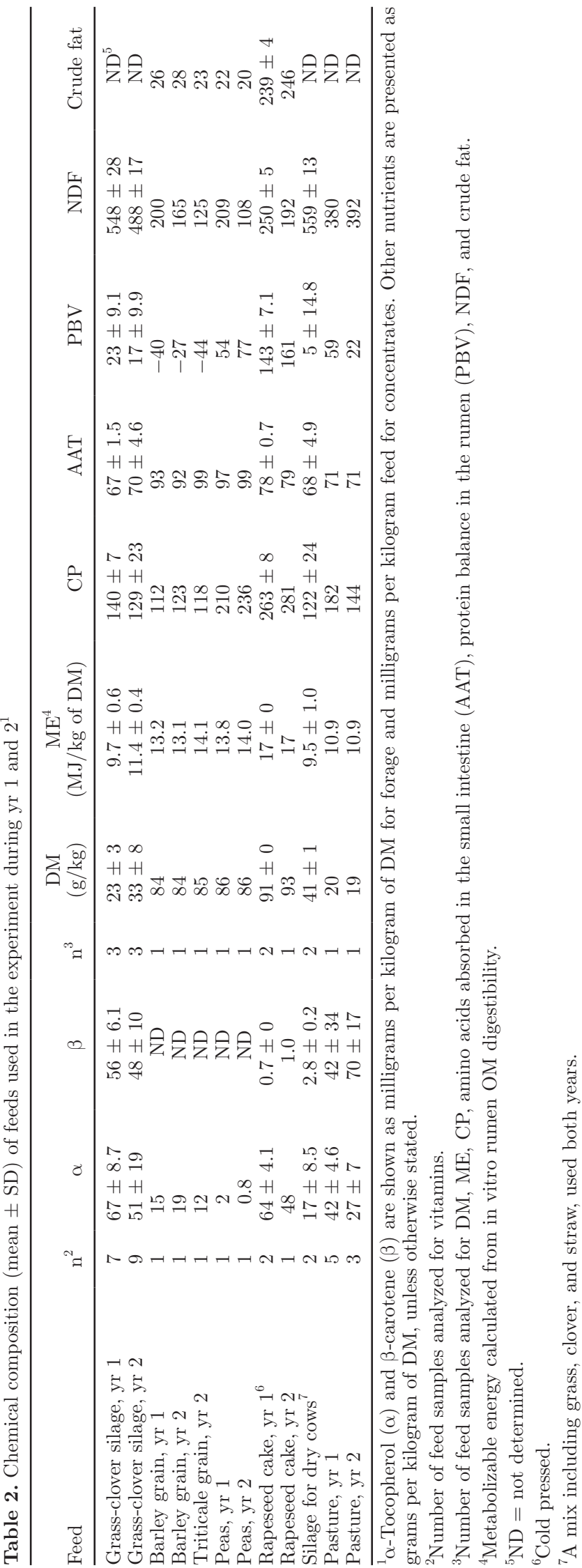

\section{Blood and Milk Sampling and Analyses}

Sampling. Five blood samples were taken from the tail vein of each cow during pregnancy and lactation. The first sample was taken $3 \mathrm{wk}$ before expected calving, the second sample within $24 \mathrm{~h}$ after calving [postcalving (PC)], and the third sample 3 to $4 \mathrm{wk}$ PC. In addition, a sample was taken in mid lactation (lactation mo 3-5) and in late lactation (lactation mo 7-9). All blood samples were collected in heparin-coated BD Vacutainer tubes (Becton Dickinson Co., Franklin Lakes, NJ), centrifuged at $1,000 \times g$ for $15 \mathrm{~min}$ at room temperature $\left(\sim 15^{\circ} \mathrm{C}\right)$ and the plasma was transferred to sample tubes and stored at $-20^{\circ} \mathrm{C}$ until analysis.

Five milk samples were collected during lactation. The first sample was taken from colostrum immediately after calving (within $15 \mathrm{~h}$ ), the second sample $4 \mathrm{~d}$ PC, and the remaining samples were taken at morning milking on the same day as blood was collected. The milk samples were frozen $\left(-20^{\circ} \mathrm{C}\right)$ until analysis.

Analyses. All blood plasma and milk samples were analyzed by HPLC using procedures described previously for concentration of retinol, $\beta$-carotene, and $\alpha$-tocopherol (Jensen and Nielsen, 1996).

\section{Milk Production and Other Recordings}

Daily milk yield was recorded individually every second week during the first 3 mo of lactation and thereafter once per month, and milk samples were collected at the same time. Milk composition (fat, protein, urea, and SCC) was analyzed by Eurofins Steins Laboratory Inc. (Jönköping, Sweden).

Body weight was recorded once per month, and the BCS of the cows was determined at the same time by 1 trained scorer, using a visual appraisal method (Edmonson et al., 1989). All veterinary registered cases of disease were recorded continuously as a measure of cow health. Mastitis was diagnosed according to ordinary farm routines, with symptoms of flakes and clots in milk and a swollen udder.

\section{Statistical Analyses}

The long-term effect of treatment was tested as the interaction between year and treatment, but no interaction was found. Therefore, year was excluded from the model and data on vitamin status and production were analyzed separately for each year. However, among the health parameters, differences were found between years within treatments, and year was, therefore, kept in the model. Statistical ANOVA was carried out for vitamin concentrations in blood and milk, using PROC MIXED of SAS (SAS Institute, 2003). Data from the 
first 3 samples (in conjunction with calving) were regarded as repeated measurements and the statistical model included treatment, sampling time, and the 2 -way interaction between treatment and sampling time. Effect of cow pair was treated as a random effect. The $P$-values were adjusted with the Tukey-Kramer adjustment. For samples taken in mid and late lactation, the model included treatment, and cow pair was treated as a random effect.

Milk production data and BW, BCS, and SCC were analyzed as means for the first 3 mo of lactation, and as means for the following lactation mo up to $305 \mathrm{~d}$ of lactation. Statistical ANOVA was carried out using PROC GLM of SAS (SAS Institute, 2003). The statistical model included treatment and cow pair. Values for SCC in milk were logarithmically transformed (natural logarithm) to obtain a normal distribution of the data. The GLM procedure was used as the most common ANOVA and PROC MIXED was used for repeated measurements and when risk of imbalanced data occurred.

Vitamin concentrations, milk yield, milk composition, BW, BCS, and natural logarithm of SCC (lnSCC) are presented as least squares means with standard error of the mean. The back-transformed SCC values are presented for clarification.

For each treatment group (NSV and CON) and year, the number of animals with no diseases and the numdiseases were recorded. Statistical analyses were performed (comparisons between treatments within each category, within each year, and between years) with the Fisher exact test. Results with a $P$-value $<0.05$ were regarded as significantly different, whereas $0.05<P<$ 0.10 indicated that the results tended to be significant.

\section{RESULTS}

\section{Concentrations of $\alpha$-Tocopherol, $\beta$-Carotene, and Retinol}

Blood Plasma. For $\alpha$-tocopherol in yr 1 and 2, and $\beta$-carotene and retinol in yr 1 , an overall effect of time was observed from $3 \mathrm{wk}$ before expected calving to 3 to 4 wk PC (Table 3). The samples taken at calving had the lowest concentrations, except for $\beta$-carotene in yr 1 , when no differences existed between samples taken at calving and 3 to 4 wk PC. Treatment had no significant effect in any of the years, but at 3 to $5 \mathrm{mo} \mathrm{PC}$ in yr 1 , a tendency existed for NSV cows to have a higher $\beta$-carotene concentration than CON cows (Tables 3 and $4)$.

Milk. In both years, an overall significant effect of time was observed for all parameters studied, with a ber of cows treated for milk fever, mastitis, or other

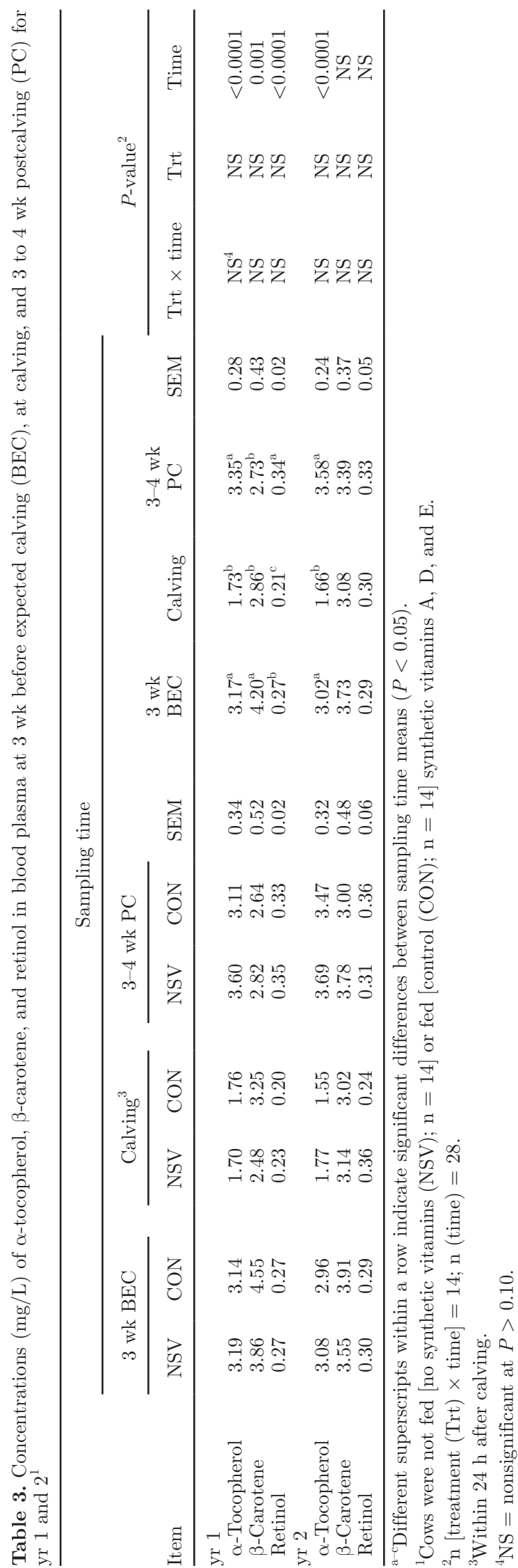

Journal of Dairy Science Vol. 97 No. 3, 2014 
Table 4. Concentrations (mg/L) of $\alpha$-tocopherol, $\beta$-carotene, and retinol in blood plasma at 3 to 5 mo postcalving (PC) and 7 to 9 mo PC for yr 1 and $2^{1}$

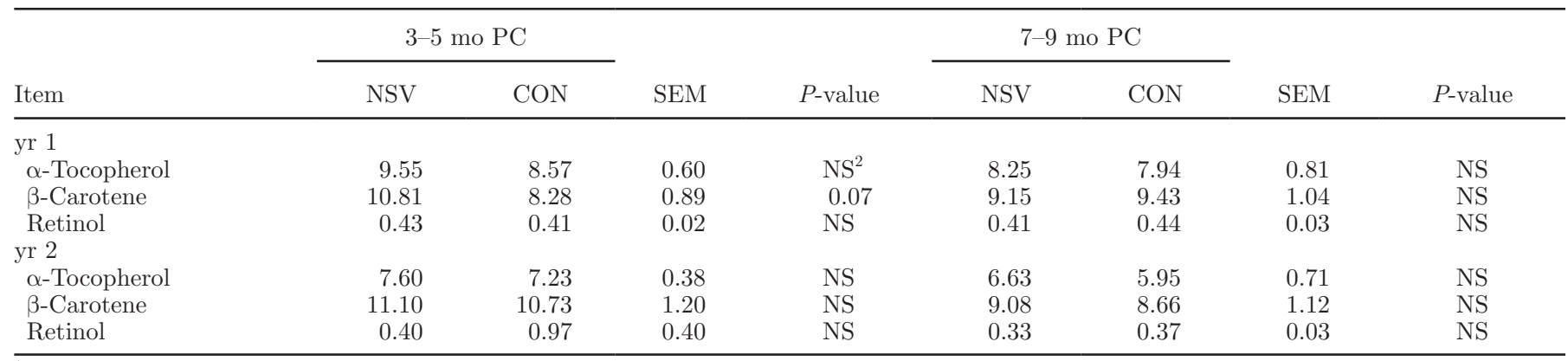

${ }^{1}$ Cows were not fed [no synthetic vitamins $\left.(\mathrm{NSV}) ; \mathrm{n}=14\right]$ or fed $[$ control $(\mathrm{CON}) ; \mathrm{n}=14]$ synthetic vitamins $\mathrm{A}, \mathrm{D}$, and $\mathrm{E}$.

${ }^{2} \mathrm{NS}=$ nonsignificant at $P>0.10$.

higher concentration in colostrum than in milk samples taken $4 \mathrm{~d}$ and 3 to 4 wk PC (Table 5 ). The only differences between treatment groups were found in colostrum in yr 1 , when $\beta$-carotene concentration was higher and $\alpha$-tocopherol concentration tended to be higher in CON cows than in NSV cows (Tables 5 and 6).

\section{Milk Production and Body Condition}

No significant differences in milk yield $(\mathrm{kg})$, milk composition, milk urea, BCS, or BW were found between treatments (Table 7).

\section{Cow Health}

In yr 1 , no health differences were observed between treatments, but in yr 2, the number of cows veterinary treated for mastitis tended to be higher in NSV cows than in CON cows (Table 8). In the NSV group, there were fewer healthy cows in yr 2 than in yr 1 (Table 8). In the same group, more cows were veterinary treated for mastitis during yr 2 than during yr 1 . In the CON group, no differences were observed between the years.

The mean SCC for the first 3 mo of lactation in yr 1 was 36,315 and 44,356 cells $/ \mathrm{mL}$ in the NSV and CON group, respectively $(\operatorname{lnSCC}=10.5$ and 10.7 ; $\mathrm{SEM}=$ $0.16 ; P=0.37)$, whereas the mean SCC for test milkings after 3 mo of lactation was 73,130 and 109,099 cells $/ \mathrm{mL}$, respectively $(\operatorname{lnSCC}=11.2$ and 11.6 ; SEM $=$ $0.11 ; P=0.01)$. In yr 2 , the mean SCC for the first 3 mo of lactation was 162,755 and 98,716 cells $/ \mathrm{mL}$ in the $\mathrm{NSV}$ and CON treatment, respectively $(\operatorname{lnSCC}=12.0$ and $11.5 ; \mathrm{SEM}=0.27 ; P=0.27$ ), whereas the mean SCC for the test milkings after 3 mo of lactation was 268,337 and 162,755 cells $/ \mathrm{mL}$, respectively $(\mathrm{lnSCC}=$ 12.5 and 12.0; $\mathrm{SEM}=0.15 ; P=0.05)$.

\section{DISCUSSION}

In this study, we found few differences in vitamin and provitamin concentrations in blood plasma and milk between cows that had been supplemented with synthetic vitamins (CON group) and nonsupplemented cows (NSV group). However, the NSV cows tended to have higher milk SCC during yr 2 of the study than the CON cows. Moreover, fewer NSV cows were healthy in yr 2 than in yr 1 of the study, which might indicate a long-term effect of not receiving vitamin supplementation.

An earlier study showed that vitamin supplementation had less effect on the vitamin status of the cows when higher concentrations of vitamins were present in the forage than when the forage had lower concentrations (approximately 65 compared with $22 \mathrm{mg}$ of $\alpha$-tocopherol/kg of DM; Lindqvist et al., 2011). In the present study, the forage had about the same level of $\alpha$-tocopherol and $\beta$-carotene as that with high concentrations of vitamins in the study of Lindqvist et al. (2011). It is known that natural vitamin E, which is available in forage, has higher bioavailability than synthetic vitamin $\mathrm{E}$ and that supplementation with natural vitamin $\mathrm{E}$ to dairy cows results in higher concentrations of $\alpha$-tocopherol in cow blood plasma than supplementation with synthetic vitamin E (Meglia et al., 2006; Weiss et al., 2009; Mogensen et al., 2012). Natural vitamin $\mathrm{E}$ consists of $R R R$ - $\alpha$-tocopherol, whereas synthetic vitamin $\mathrm{E}$ is a mixture of 8 stereoisomers of $\alpha$-tocopherol, of which the $R R R$ form is the most active form (Dersjant-Li and Peisker, 2010). However, the synthetic form of retinol (vitamin A) has been shown to have similar bioavailability to the natural form (NRC, 2001). The high vitamin concentration in forage and the differences in bioavailability between natural and synthetic vitamin E might explain the lack of differences in blood plasma and milk observed here between supplemented and nonsupplemented cows.

\section{Vitamins in Blood Plasma}

It is possible that an organic feed ration with high levels of silage, and thereby considerable amounts of 


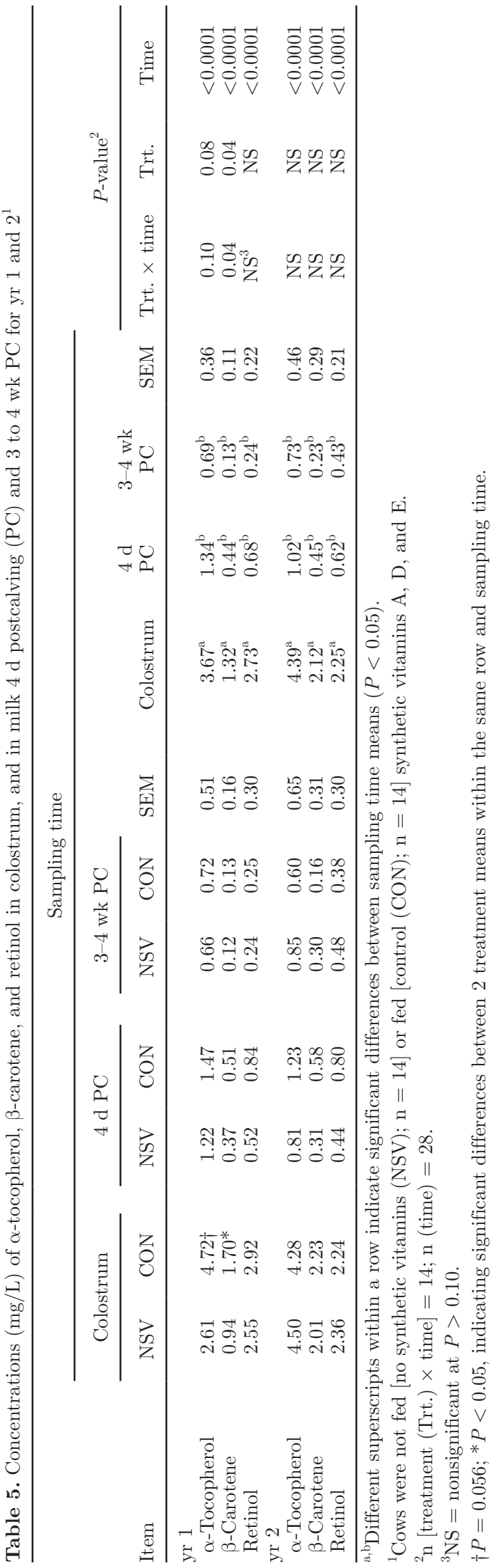

natural vitamin $\mathrm{E}$ in the diet, results in a lower uptake of synthetic vitamin $\mathrm{E}$ than when the contribution from the basal diet is low (Lindqvist et al., 2011). However, in both our treatment groups, the plasma concentrations were low around calving and especially at calving, when the $\alpha$-tocopherol concentration was significantly lower than at the other samplings. The cows in the CON group were given $600 \mathrm{IU}$ of synthetic $\alpha$-tocopherol per day, which is according to Swedish recommendations, but lower than the $>2,000$ IU per day reported to be necessary to maintain $\alpha$-tocopherol concentration in plasma at calving in another study (Weiss et al., 1997). That study also showed a much higher risk for mastitis during the first $7 \mathrm{~d}$ after calving when the concentration of $\alpha$-tocopherol was below $3 \mathrm{mg} / \mathrm{L}$ of plasma and, in our study, the concentration was below $2 \mathrm{mg} / \mathrm{L}$ of plasma in both treatments and years, which is regarded as deficient (Frye et al., 1991).

The concentration of $\beta$-carotene at calving was 2.86 and $3.08 \mathrm{mg} / \mathrm{L}$ of plasma in yr 1 and 2, respectively, which is acceptable according to Jukola et al. (1996). However, the retinol concentrations were somewhat low $(0.21$ and $0.30 \mathrm{mg} / \mathrm{L}$ of plasma in yr 1 and 2, respectively) compared with the $0.4 \mathrm{mg} / \mathrm{L}$ recommended for unimpaired udder health (Jukola et al., 1996). Even the nonsupplemented cows in our study had enough provitamin $\mathrm{A}$ ( $\beta$-carotene) in their basal diet to meet the vitamin A recommendations when calculated as milligrams of $\beta$-carotene $\times 400 \mathrm{IU}$. However, the conversion factor to vitamin A has not been experimentally determined in cattle, but mainly in lambs (NRC, 2001) and it might, therefore, be misleading. The calculated intake, which showed satisfactory vitamin A intake from the basal diet, may therefore have been too high, which could explain the low retinol concentrations in blood plasma. The level of $\beta$-carotene tended to be lower in the blood plasma of CON cows than of NSV cows at 3 to 5 mo PC. Competition between $\alpha$-tocopherol and $\beta$-carotene when cows are given extra $\alpha$-tocopherol has been discussed (Weiss et al., 1994). However, the plasma concentrations in the present study were well above the recommended level in both groups, and should not have affected cow health or production.

\section{Vitamins in Milk}

The higher $\beta$-carotene concentration and the tendency for higher $\alpha$-tocopherol concentration in colostrum from supplemented CON cows than in NSV cows in yr 1 agrees with findings from other studies (Lindqvist et al., 2011). It has been shown that $\alpha$-tocopherol can protect $\beta$-carotene from oxidation, which may be a reason for the larger difference in $\beta$-carotene than in $\alpha$-tocopherol (Munne-Bosch, 2005). The level of $\alpha$-tocopherol in co- 
Table 6. Concentrations (mg/L) of $\alpha$-tocopherol, $\beta$-carotene, and retinol in milk at 3 to 5 mo postcalving (PC) and 7 to 9 mo PC for yr 1 and $2^{1}$

\begin{tabular}{|c|c|c|c|c|c|c|c|c|}
\hline Item & \multicolumn{2}{|c|}{$3-5$ mo PC } & SEM & $P$-value & \multicolumn{2}{|c|}{ 7-9 mo PC } & SEM & $P$-value \\
\hline \multicolumn{9}{|l|}{ yr 1} \\
\hline$\beta$-Carotene & 0.12 & 0.13 & 0.02 & NS & 0.15 & 0.16 & 0.02 & NS \\
\hline Retinol & 0.23 & 0.23 & 0.02 & NS & 0.29 & 0.31 & 0.03 & NS \\
\hline \multicolumn{9}{|l|}{ yr 2} \\
\hline Retinol & 0.37 & 0.37 & 0.02 & NS & 0.38 & 0.42 & 0.03 & NS \\
\hline
\end{tabular}

${ }^{1}$ Cows were not fed [no synthetic vitamins $(\mathrm{NSV}) ; \mathrm{n}=14$ ] or fed [control $(\mathrm{CON}) ; \mathrm{n}=14$ ] synthetic vitamins $\mathrm{A}, \mathrm{D}$, and E.

${ }^{2} \mathrm{NS}=$ nonsignificant at $P>0.10$.

lostrum was above $4 \mathrm{mg} / \mathrm{L}$ of milk, except in NSV cows in yr 1, when the concentration was below $3 \mathrm{mg} / \mathrm{L}$. The vitamin concentration in colostrum is of great importance for the immune defense of the calf (Van Saun et al., 1989). In Swedish dairy herds, inadequate serum concentrations of $\alpha$-tocopherol and $\beta$-carotene were reported to be associated with higher calf mortality (Torsein et al., 2011). Additionally, a lower risk of stillbirth or calf death within $24 \mathrm{~h}$ after birth has been observed in cows fed extra vitamin supplements around calving (Persson Waller et al., 2007).

No differences existed between treatments in vitamin concentrations in milk from d 4 throughout lactation in yr 1 or 2 , which could be due to sufficient levels of vitamins in the basal diet. A positive correlation between vitamin supply from forage and vitamins in milk has been reported (Agabriel et al., 2007; Mogensen et al., 2012) and cows preferentially take up the $R R R-\alpha-$ tocopherol stereoisomer found in vitamin $\mathrm{E}$ in forage, compared with the $2 \mathrm{~S}$ isomers, which comprise $50 \%$ of the tocopherol found in all-rac (Weiss et al., 2009).
Increased uptake of plasma vitamin E by the mammary gland has also been observed in cows fed diets rich in PUFA (Durand et al., 2005). Comparisons of vitamin concentrations in milk from organic and conventional herds have produced varied results (Ellis et al., 2007; Fall and Emanuelson, 2011) and the levels recorded are probably more dependent on type of roughage and inclusions of oilseeds than on system.

\section{Health and Milk Production}

The NSV cows had lower lnSCC than the CON cows after 3 mo of lactation in yr 1 , but in yr 2 , the situation was reversed. The tendency for a higher $\operatorname{lnSCC}$ in NSV cows after $3 \mathrm{mo}$ of lactation in yr 2 is in agreement with findings in other studies (e.g., showing $25 \%$ lower SCC in cows supplemented with synthetic vitamin E compared with nonsupplemented cows in early lactation; Politis et al., 2004). It is also in accordance with the tendency for higher mastitis incidence in yr 2 in NSV cows than in CON cows. In addition, a long-term

Table 7. Milk yield, milk composition, BCS, and BW of cows during the first 3 mo of lactation and after 3 mo of lactation up to 305 d of lactation $^{1}$

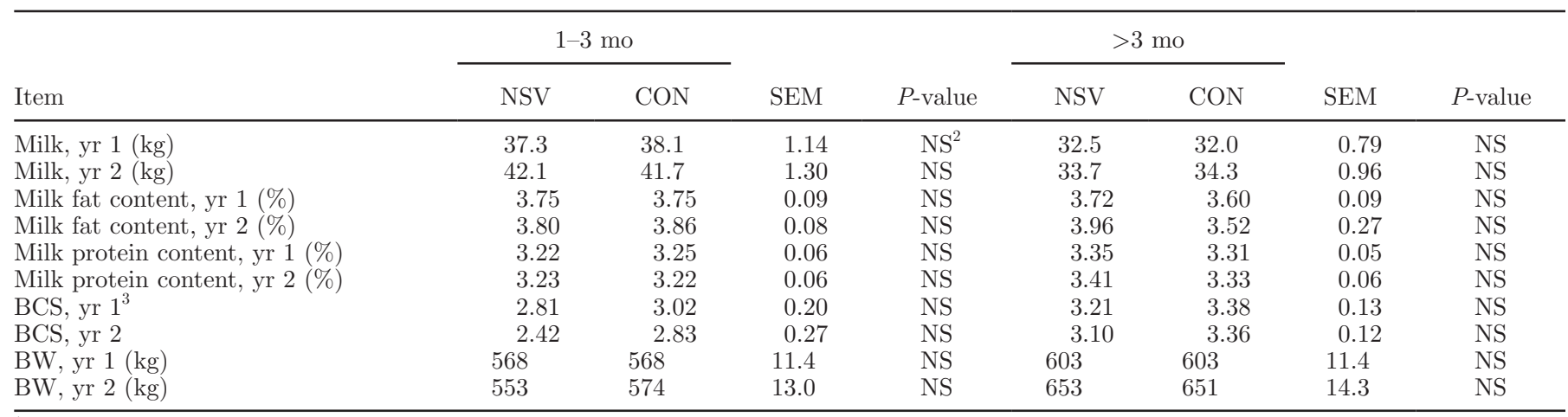

${ }^{1}$ Cows were not fed [no synthetic vitamins (NSV); $\mathrm{n}=14$ ] or fed [control $\left.(\mathrm{CON}) ; \mathrm{n}=14\right]$ synthetic vitamins A, D, and E. Results are expressed as LSM and SEM during yr 1 and 2.

${ }^{2} \mathrm{NS}=$ nonsignificant at $P>0.10$.

${ }^{3}$ Judged on a scale from 1 to 5 , in which 1 is extremely lean and 5 is excessively fat (Edmonson et al., 1989). 
Table 8. Number (and percentage within parentheses) of healthy cows and cows requiring veterinary treatment in the groups not fed [no synthetic vitamins (NSV); $\mathrm{n}=14]$ and fed [control $(\mathrm{CON}) ; \mathrm{n}=14$ ] synthetic vitamins

\begin{tabular}{|c|c|c|c|c|c|c|c|c|}
\hline \multirow{2}{*}{$\begin{array}{l}\text { Health } \\
\text { status }\end{array}$} & \multicolumn{2}{|c|}{ NSV } & \multirow[b]{2}{*}{$P$-value } & \multicolumn{2}{|c|}{$\mathrm{CON}$} & \multirow[b]{2}{*}{$P$-value } & \multicolumn{2}{|c|}{ NSV vs. CON ( $P$-value) } \\
\hline & yr 1 & yr 2 & & yr 1 & yr 2 & & yr 1 & yr 2 \\
\hline Paresis & $0(0)$ & $3(21)$ & NS & $2(14)$ & $4(28)$ & NS & NS & NS \\
\hline Mastitis & $1(7)$ & $9(64)$ & 0.002 & $2(14)$ & $4(28)$ & NS & NS & 0.06 \\
\hline Other & $2(14)$ & $4(28)$ & NS & $4(7)$ & $3(21)$ & NS & NS & NS \\
\hline
\end{tabular}

${ }^{1} \mathrm{NS}=$ nonsignificant at $P>0.10$.

effect was seen in NSV cows, with higher mastitis incidence and fewer healthy cows in yr 2 than in yr 1 . The reasons for the poorer health in NSV cows than in CON cows yr 2 are not clear, as no similar treatment effects were observed on $\alpha$-tocopherol or $\beta$-carotene. As has been reported elsewhere (Hymøller et al., 2009), however, vitamin D concentrations in plasma were lower in NSV cows \{approximately $2 \mathrm{ng}$ of 25 -hydroxyvitamin $\left.\mathrm{D}_{3}\left[25(\mathrm{OH}) \mathrm{D}_{3}\right] / \mathrm{mL}\right\}$ than in CON cows (approximately $10 \mathrm{ng} / \mathrm{mL}$ ) during the indoor periods, which could have had a negative influence on immune functions in the NSV group, possibly explaining the higher mastitis incidence (Nelson et al. 2012). Many factors related to cows, housing, and management may be risk factors for mastitis. In the current study, care was taken to ensure that the 2 treatment groups were similar in those aspects. The 2 groups were, however, housed in separate pens, making it possible that an udder infection, accidentally introduced to the NSV pen in yr 2, may have spread among cows only in that pen.

In the present study, no differences were observed between treatment groups in terms of milk yield, milk composition, BW, or BCS. Some previous studies have shown a positive effect on milk production, including milk yield, from supplementation with $\alpha$-tocopherol (Weiss et al., 1990) or $\beta$-carotene (Aréchiga et al., 1998). However, other studies report no effect of $\alpha$-tocopherol supplementation on milk yield (Politis et al., 2004; Persson Waller et al., 2007). Moreover, lower milk yield has been observed in cows fed extra $\alpha$-tocopherol in the transition period (Lindqvist et al., 2011) or very high levels of $\beta$-carotene during the dry period (Puvogel et al., 2005), which could be due to increased apoptotic rates of mammary cells (Puvogel et al., 2005). In the present study, which used good-quality silage, cows probably had access to sufficient amounts of vitamins from the basal feeds. Thus, vitamin supplementation did not affect milk yield.

As antioxidants, vitamin $\mathrm{E}$ and $\beta$-carotene increase the oxidative stability of milk (Charmley et al., 1993). As reported in a previous publication (Danielsson et al., 2007), we did not find any treatment differences in the content of unsaturated FA in milk or in number of samples with oxidized flavors, except for a higher proportion of samples with oxidized flavors in milk from NSV cows in July, when cows were at pasture and the content of unsaturated FA was higher than in other months.

Normally, cows at pasture should be able to recover their vitamin status after the indoor period due to a high vitamin concentration in growing plants (Lindqvist et al., 2012). However, concentrations of $\alpha$-tocopherol and $\beta$-carotene in the present study were lower in pasture samples than in silage samples, and the reason for this is unknown.

\section{CONCLUSIONS}

No differences were found between vitamin-supplemented and nonsupplemented cows in terms of plasma concentrations of $\alpha$-tocopherol, $\beta$-carotene, or retinol, but an effect of supplementation on colostrum composition and cow health was observed. Nonsupplemented cows tended to have more cases of mastitis and higher SCC than supplemented cows in yr 2. Within the nonsupplemented group, fewer cows were healthy in yr 2 than in yr 1. Supplementation with synthetic vitamin E according to Swedish recommendations (based on NRC guidelines) resulted in low concentrations of $\alpha$-tocopherol during the transition period around calving in both supplemented and nonsupplemented cows. Supplementation with synthetic vitamin A together with $\beta$-carotene from basal feeds seems to give an acceptable $\beta$-carotene concentration at calving in blood plasma, but a rather low concentration of retinol. These results indicate that cows in organic dairy production can fulfill their requirements of vitamins $\mathrm{A}$ and $\mathrm{E}$ without any synthetic vitamin supplementation. However, supplementation is needed around calving to avoid health problems in cows and their calves, probably at a higher level than recommended today. The impaired health of nonsupplemented cows in yr 2 may indicate a long-term negative effect on health in cows fed no synthetic vitamins. 


\section{ACKNOWLEDGMENTS}

This experiment was funded by the Swedish Board of Agriculture (Jönköping, Sweden). The Swedish Rural Economy and Agricultural Societies (Uddevalla, Sweden) supplied the cows and the stable, and are gratefully acknowledged. Special thanks to Erik Hedlund, head of Tingvall farm (southwest Sweden). The mineral feeds were supplied by Lantmännen Inc., which we gratefully acknowledge. We also thank Lars Johansson (Department of Animal Environment and Health, Swedish University of Agricultural Sciences, Skara) for technical assistance, Jan-Eric Englund (Department of Biosystems and Technology, Swedish University of Agricultural Sciences, Alnarp) for statistical advice, and the staff at the Department of Animal Sciences (Aarhus University, Tjele, Denmark) for laboratory and supervisory support.

\section{REFERENCES}

Agabriel, C., A. Cornu, C. Journal, C. Sibra, P. Grolier, and B. Martin. 2007. Tanker milk variability according to farm feeding practices: Vitamins A and E, carotenoids, color, and terpenoids. J. Dairy Sci. 90:4884-4896.

Aréchiga, C. F., C. R. Staples, L. R. McDowell, and P. J. Hansen. 1998. Effects of timed insemination and supplemental $\beta$-carotene on reproduction and milk yield of dairy cows under heat stress. J. Dairy Sci. 81:390-402.

Baldi, A. 2005. Vitamin E in dairy cows. Livest. Prod. Sci. 98:117122.

Calderón, F., B. Chauveau-Duriot, P. Pradel, B. Martin, B. Graulet, M. Doreau, and P. Nozière. 2007. Variations in carotenoids, vitamins $\mathrm{A}$ and $\mathrm{E}$, and color in cow's plasma and milk following a shift from hay diet to diets containing increasing levels of carotenoids and vitamin E. J. Dairy Sci. 90:5651-5664.

Charmley, E., J. W. G. Nicholson, and J. A. Zee. 1993. Effect of supplemental vitamin $\mathrm{E}$ and selenium in the diet on vitamin $\mathrm{E}$ and selenium levels and control of oxidized flavor in milk from Holstein cows. Can. J. Anim. Sci. 73:453-457.

Chew, B. P. 1987. Symposium: Immune Function: Relationship of Nutrition and Disease Control. Vitamin A and $\beta$-carotene on host defense. J. Dairy Sci. 70:2732-2743.

Chew, B. P. 1993. Role of carotenoids in the immune response. J. Dairy Sci. 76:2804-2811.

Coelho, M. B. 1991. Vitamin stability in premixes and feeds: A practical approach. Pages 56-71 in Proc. BASF Technical Symposium, Bloomington, MN.

Danielsson, H., B. Johansson, E. Nadeau, K. Persson Waller, and S. K. Jensen. 2007. Fatty acids and flavours in milk from dairy cows fed no synthetic vitamins. J. Anim. Feed Sci. 16(Suppl. 1):59-64.

Dersjant-Li, Y., and M. Peisker. 2010. Utilization of stereoisomers from alpha-tocopherol in livestock animals. J. Anim. Physiol. Anim. Nutr. (Berl.) 94:413-421.

Drackley, J. K. 1999. Biology of dairy cows during the transition period: The final frontier? J. Dairy Sci. 82:2259-2273.

Durand, D., V. Scislowski, D. Gruffat, Y. Chilliard, and D. Bauchart. 2005. High-fat rations and lipid peroxidation in ruminants: Consequences on the health of animals and quality of their products. Pages 137-150 in Indicators of Milk and Beef Quality. J. F. Hocquette and S. Gigli, ed. Wageningen Academic Publishers, Wageningen, the Netherlands.

EC (European Commission). 1999. Council Regulation (EC) No. 1804/1999 of 19 July 1999 supplementing Regulation (EEC) No. 2029/91 on organic production of agricultural products and indi- cations referring thereto on agricultural products and foodstuffs to include livestock production. Official Journal of the European Communities L222:1-28. European Commission, Brussels, Belgium.

EC (European Commission). 2005. Commission Regulation (EC) No. 1916/2005 of 24 November 2005 amending Annex II to Council Regulation (EEC) No. 2092/91 on organic production of agricultural products and indications referring thereto on agricultural products and foodstuffs. Official Journal of the European Communities L307/10. European Commission, Brussels, Belgium.

Edmonson, A. J., I. J. Lean, L. D. Weaver, T. Farver, and G. Webster. 1989. A body condition scoring chart for Holstein dairy cows. J. Dairy Sci. 72:68-78.

Ellis, K. A., A. Monteiro, G. T. Innocent, D. Grove-White, P. Cripps, W. G. McLean, C. V. Howard, and M. Mihm. 2007. Investigation of the vitamins $\mathrm{A}$ and $\mathrm{E}$ and beta-carotene content in milk from UK organic and conventional dairy farms. J. Dairy Res. 74:484-491.

Fall, N., and U. Emanuelson. 2011. Fatty acid content, vitamins and selenium in bulk tank milk from organic and conventional Swedish dairy herds during the indoor season. J. Dairy Res. 78:287-292.

Frye, T. M., S. N. Williams, and T. W. Graham. 1991. Vitamin deficiencies in cattle. Vet. Clin. North Am. Food Anim. Pract. $7: 217-275$.

Hymøller, L., S. K. Jensen, H. Lindqvist, B. Johansson, M. O. Nielsen, and E. Nadeau. 2009. Supplementing dairy steers and organically managed dairy cows with synthetic vitamin $\mathrm{D}_{3}$ is unnecessary at pasture during exposure to summer sunlight. J. Dairy Res. $76: 372-378$.

Jensen, S. K., and K. N. Nielsen. 1996. Tocopherols, retinol, betacarotene and fatty acids in fat globule membrane and fat globule core in cows' milk. J. Dairy Res. 63:565-574.

Johansson, B., and E. Nadeau. 2006. Performance of dairy cows fed an entirely organic diet containing cold-pressed rapeseed cake. Acta Agric. Scand. A Anim. Sci. 56:128-136.

Jukola, E., J. Hakkarainen, H. Saloniemi, and S. Sankari. 1996. Blood selenium, vitamin $\mathrm{E}$, vitamin $\mathrm{A}$, and $\beta$-carotene concentrations and udder health, fertility treatments, and fertility. J. Dairy Sci. 79:838-845.

Kume, S., and T. Toharmat. 2001. Effect of colostral $\beta$-carotene and vitamin A on vitamin and health status of newborn calves. Livest. Prod. Sci. 68:61-65.

Lindqvist, H., E. Nadeau, and S. K. Jensen. 2012. Alpha-tocopherol and $\beta$-carotene in legume-grass mixtures as influenced by wilting, ensiling and type of silage additive. Grass Forage Sci. 67:119-128.

Lindqvist, H., E. Nadeau, K. Persson Waller, S. K. Jensen, and B. Johansson. 2011. Effects of RRR- $\alpha$-tocopheryl acetate supplementation during the transition period on vitamin status in blood and milk of organic dairy cows during lactation. Livest. Sci. 142:155163.

Madsen, J., T. Hvelplund, M. R. Weisbjerg, J. Bertilsson, I. Olsson, R. Spörndly, O. M. Harstad, H. Volden, M. Tuori, T. Varvikko, P. Huhtanen, and B. L. Olafsson. 1995. The AAT/PBV protein evaluation system for ruminants: A revision. Nor. J. Agric. Sci 19(Suppl.):1-37.

Meglia, G. E., S. K. Jensen, C. Lauridsen, and K. Persson Waller. 2006. $\alpha$-Tocopherol concentration and stereoisomer composition in plasma and milk from dairy cows fed natural or synthetic vitamin E around calving. J. Dairy Res. 73:227-234.

Mogensen, L., T. Kristensen, K. Søegaard, S. K. Jensen, and J. Sehested. 2012. Alfa-tocopherol and beta-carotene in roughages and milk in organic dairy herds. Livest. Sci. 145:44-54.

Munné-Bosch, S. 2005. The role of $\alpha$-tocopherol in plant stress tolerance. J. Plant Physiol. 162:743-748.

Nelson, C. D., T. A. Reinhardt, J. D. Lippolis, R. E. Sacco, and B. J. Nonnecke. 2012. Vitamin D signaling in the bovine immune system: A model for understanding human vitamin D requirements. Nutrients 4:181-196.

NRC. 2001. Nutrient Requirements of Dairy Cattle. 7th rev. ed. National Academy Press, Washington, DC 
Persson Waller, K., C. Hallén Sandgren, U. Emanuelson, and S. K. Jensen. 2007. Supplementation of $R R R$ - $\alpha$-tocopheryl acetate to periparturient dairy cows in commercial herds with high mastitis incidence. J. Dairy Sci. 90:3640-3646.

Politis, I., I. Bizelis, A. Tsiaras, and A. Baldi. 2004. Effect of vitamin E supplementation on neutrophil function, milk composition and plasmin activity in dairy cows in a commercial herd. J. Dairy Res. 71:273-278.

Politis, I., N. Hidiroglou, J. H. White, J. A. Gilmore, S. N. Williams, H. Scherf, and M. Frigg. 1996. Effects of vitamin E on mammary and blood leukocyte function, with emphasis on chemotaxis, in periparturient dairy cows. Am. J. Vet. Res. 57:468-471.

Puvogel, G., C. R. Baumrucker, H. Sauerwein, R. Rühl, E. Ontsouka, H. M. Hammon, and J. W. Blum. 2005. Effects of an enhanced vitamin A intake during the dry period on retinoids, lactoferrin, IGF system, mammary gland epithelial cell apoptosis, and subsequent lactation in dairy cows. J. Dairy Sci. 88:1785-1800.

SAS Institute. 2003. SAS 9.1 User's Guide: Statistics. SAS Institute Inc., Cary, NC.

Torsein, M., A. Lindberg, C. Hallén Sandgren, K. Persson Waller, M. Törnquist, and C. Svensson. 2011. Risk factors for calf mortality in large Swedish dairy herds. Prev. Vet. Med. 99:136-147.

Vagni, S., F. Saccone, L. Pinotti, and A. Baldi. 2011. Vitamin E bioavailability: Past and present insights. Food Nutr. Sci. 2:10881096.
Van Saun, R. J., T. H. Herdt, and H. D. Stowe. 1989. Maternal and fetal vitamin $\mathrm{E}$ concentrations and selenium-vitamin E interrelationships in dairy cattle. J. Nutr. 119:1156-1164.

Weiss, W. P., J. S. Hogan, K. L. Smith, and K. H. Hoblet. 1990. Relationships among selenium, vitamin E, and mammary gland health in commercial dairy herds. J. Dairy Sci. 73:381-390.

Weiss, W. P., J. S. Hogan, K. L. Smith, and S. N. Williams. 1994. Effect of dietary fat and vitamin $\mathrm{E}$ on $\alpha$-tocopherol and $\beta$-carotene in blood of peripartum cows. J. Dairy Sci. 77:1422-1429.

Weiss, W. P., J. S. Hogan, D. A. Todhunter, and K. L. Smith. 1997. Effect of vitamin E supplementation in diets with a low concentration of selenium on mammary gland health of dairy cows. J. Dairy Sci. 80:1728-1737.

Weiss, W. P., J. S. Hogan, and D. J. Wyatt. 2009. Relative bioavailability of all-rac and RRR vitamin E based on neutrophil function and total $\alpha$-tocopherol and isomer concentrations in periparturient dairy cows and their calves. J. Dairy Sci. 92:720-731.

Weiss, W. P., K. L. Smith, J. S. Hogan, and T. E. Steiner. 1995. Effect of forage to concentrate ratio on disappearance of vitamins $\mathrm{A}$ and E during in vitro ruminal fermentation. J. Dairy Sci. 78:18371842 . 